\title{
Genetic Parameters of Growth Traits and Wood Density in Eucalyptus grandis Progenies Planted in Argentina
}

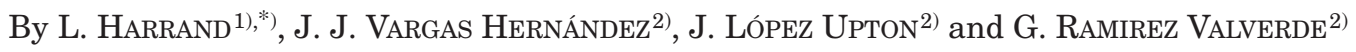

(Received $8^{\text {th }}$ June 2007)

\begin{abstract}
To determine the genetic parameters of growth traits and wood density (estimated by Pilodyn penetration) in a population of Eucalyptus grandis formed by families from 11 seed origins in NE Queensland, Australia and a local land race, 8.5-year-old progenies established in three sites in NE Argentina were evaluated. Local trees exhibited higher growth rate at two sites and better stem form, but also deeper Pilodyn penetration, at all sites; thus, there is potential to infuse new genetic variation into the current breeding population in the region. A significant amount of genetic variation was found for all traits assessed, with growth traits [diameter (DBH), height (HT) and volume (VOL)] showing different genetic structure and degree of genetic control as compared to stem straightness (FORM), bark thickness (BARK) and Pilodyn penetration (PILO). The effect of origin was negligible for growth traits while it was important for the other traits, so it should be considered in the selection strategy; in addition, individual heritability for growth traits (0.11-0.16 in the combined analyses) was generally lower than for the other traits (0.20-0.35). Genetic correlations between sites for all traits were high enough to indicate that genotype-environment interaction would not affect the selection program by using a single breeding population for this region. Genetic correlations between growth traits were high $\left(\mathrm{r}_{\mathrm{s}}>0.80\right)$, and negligible between these and FORM; the only unfavorable genetic correlation was between PILO and BARK $\left(r_{g}=-0.44\right)$. Age-age correlations for growth traits and FOORM were very high $\left(r_{r}>0.90\right)$. Results suggest that all traits evaluated could be handled in a breeding program, either independently or combined, without negative correlated effects. Early selection for growth traits and stem form is also possible, with major savings in time.
\end{abstract}

Key words: Heritability, genetic correlation, age-age correlation, genetic stability, variance components, Pilodyn.

\section{Introduction}

Eucalyptus grandis Hill ex Maiden is native to Australia, having its major distribution range in northern New South Wales and southern Queensland, between $25^{\circ}$ and $33^{\circ} \mathrm{S}$, from sea level to $600 \mathrm{~m}$. Smaller stands are found in the northern region of Queensland ( $16^{\circ}$ to $19^{\circ} \mathrm{S}$ ) from 500 to $1100 \mathrm{~m}$ (Boland et al., 1984). It is one of the most widely planted forest species throughout the

\footnotetext{
1) INTA EEA Concordia. CC 34. CP 3200. Concordia. Entre Ríos. Argentina. Tel/Fax: ++54 3454290000 .

2) Campus Montecillo. Colegio de Postgraduados. CP 56230. Montecillo, Estado de México. México. E-Mail: vargashj@colpos. $\underline{\mathrm{mx}}$, uptonj@colpos.mx, gramirez@colpos.mx

*) Author for correspondence: LEONEL HARRAND.

E-Mail: lharrand@correo.inta.gov.ar
}

world because of its adaptability and versatility of use as lumber (SÁNCHEZ-ACOSTA, 1999). In Argentina, over 200,000 hectares are planted with this species across the provinces of Entre Ríos, Corrientes and Misiones, in the mesopotamic region (BRAIER, 2004).

Breeding programs are aimed at obtaining improved populations with the largest possible number of desirable traits (VIANA, 2001). Thus, identification of parents and traits to be included as selection criteria is critical for a successful breeding program. The decision becomes complex when the genetic evaluation program includes material from different geographic origins and several traits contribute to economic value, since each trait might have different genetic structure. Genetic structure refers to the magnitude of genetic variances and covariances among and within populations (seed origins), influencing genetic parameters of traits, and therefore, genetic gains (WHITE and Hodge, 1989). The genetic structure of traits affects the initial approach of the breeding program. For instance, VOLKER and RAYMOND (1988) suggest that the best approach to increase growth rate in $E$. globulus is to include families from all origins in the selected population; however, if wood density is included in the breeding objective, the effect of races should be considered first.

Estimation of genetic parameters for a particular trait has an associated error that depends on several factors, such as number and size of families evaluated, number and quality of experimental sites, and genotype by environment interaction (GEI), among others (ZOBEL and TALBERT, 1984; FAlCONER and MACKAY, 1996). GEI is the result of gene expression for each genotype as a function of the growing environment (BORRALHO, 1998). The only way to identify GEI effects is to evaluate genetic tests in several environments. When genotypes are evaluated in a single site, GEI effects become "confounded" with genetic effects, causing an overestimation of genetic parameters (ZOBEL and TALBERT, 1984). In addition to having unbiased genetic parameter estimates, evaluation of GEI effects allow us to identify genotypes performing well across the environments tested, or to select specific genotypes for each environment (VAN BUIJTENEN, 1992).

In 1996, as part of the breeding program for E. grandis initiated by INTA (Instituto Nacional de Tecnología Agropecuaria - National Institute of Agricultural Technology), a progeny test was set up in northeastern Argentina with 156 open-pollinated families from 11 origins within the northern range of the species and a local land race used as control, in three evaluation sites in the mesopotamic region (SAGPYA-INTA, 2005). These origins complement earlier introductions of $E$. grandis 
from New South Wales and southern Queensland already represented in the breeding program (MARCó and WHITE, 2002), aiming to infuse new genetic variation for additional traits. The objective of this study was to evaluate the performance of $E$. grandis progenies coming from the NE region of Queensland, compared to the local land race, in terms of growth traits, stem form and wood density (measured indirectly with the Pilodyn), to determine the magnitude and importance of GEI for these traits, and to estimate the genetic parameters of traits and their implications for the breeding strategy of the species in this region.

\section{Materials and Methods}

\section{Genetic material and experimental design}

The study included a seed origin/progeny test planted in November 1996 in three sites of northeastern Argentina (Corrientes and Misiones Provinces) between $27^{\circ}$ and $28^{\circ} \mathrm{S}$ and 100 to $500 \mathrm{~m}$ above sea level (Table 1). The experimental layout used was a complete random blocks design, with single-tree plots and 20 replications per site. Open-pollinated, maternal half-sib families were used, representing 11 seed origins (natural stands) from northern Queensland (Australia), between $16^{\circ}$ and $19^{\circ} \mathrm{S}$, and a local Argentine land race used as control (Table 1). The land race was generated from seed introductions made over 60 years ago, but there is no background information about its geographic origin. A total of 126 families were included in Site 1, 112 in Site 2, and 156 in Site 3, with 111 of them common to all sites. The spacing used in all three sites was $3 \times 3 \mathrm{~m}$. Soil preparation included mechanical plowing in site 1 and slash burning after logging, without plowing, in sites 2 and 3 . Weed control was done by hand-slashing until crown closure was reached in all sites.

\section{Traits evaluated}

When trees were 4.5 years old, stem diameter at breast height (1.30 $\mathrm{m}$ from the ground, DBH_01), total tree height (HT_01), and stem straightness (FORM_01) were measured on all living trees over $5 \mathrm{~cm}$ in $\mathrm{DBH}$, since individuals with smaller DBH were clearly dominated by neighboring trees. These measurements were repeated when trees were 8.5 years old (DBH_05, HT_05, and FORM_05), considering only trees over 10 $\mathrm{cm}$ in $\mathrm{DBH}$; bark thickness and Pilodyn penetration were also measured at this age. Tree diameter and height were measured with a diametric tape and a Blume-Leiss hypsometer, respectively. Bole straightness was assessed visually on a scale of 1 (straight stem) to 4 (twisted stem). With data on $\mathrm{DBH}$ and height, total stem volume was calculated (VOL_01 and VOL_05) for each tree, using the equation developed by CRECHI et al. (2006):

$$
\begin{aligned}
\ln (\text { VOL })= & 1.00344189 *[-10.3487+3.14561 \\
& * \ln (D B H)-0.18246 * \ln ^{2}(D B H) \\
& \left.+0.145388 * \ln ^{2}(H T)\right]
\end{aligned}
$$

\begin{tabular}{|c|c|c|c|c|}
\hline & $\begin{array}{c}\text { Families } \\
\text { (No.) }\end{array}$ & $\begin{array}{c}\text { Latitude } \\
\text { (S) }\end{array}$ & $\begin{array}{c}\text { Longitude } \\
\text { (E) }\end{array}$ & $\begin{array}{c}\text { Elevation } \\
\text { (m) }\end{array}$ \\
\hline \multicolumn{5}{|l|}{ ORIGIN } \\
\hline 1. Mt Fraser / Mt Lewis (Julatten-QLD) ${ }^{\dagger}$ & 10 & $16^{\circ} 35^{\prime}$ & $145^{\circ} 16^{\prime}$ & 1000 \\
\hline 2. Mt Lewis Region (Julatten-QLD) & 7 & $16^{\circ} 35^{\prime}$ & $145^{\circ} 17^{\prime}$ & 950 \\
\hline 3. Davis Creek Road (Mareeba-QLD) & 9 & $17^{\circ} 03^{\prime}$ & $145^{\circ} 37^{\prime}$ & 750 \\
\hline 4. Tinaroo Creek Road (Atherton-QLD) & 12 & $17^{\circ} 06^{\prime}$ & $145^{\circ} 36^{\prime}$ & 1150 \\
\hline 5. Baldy S.F. (Atherton-(QLD) & 12 & $17^{\circ} 20^{\prime}$ & $145^{\circ} 25^{\prime}$ & 1000 \\
\hline 6. SSW of Atherton (QLD) & 19 & $17^{\circ} 20^{\prime}$ & $145^{\circ} 25^{\prime}$ & 1100 \\
\hline 7. Wild River (Atherton-QLD) & 9 & $17^{\circ} 22^{\prime}$ & $145^{\circ} 24^{\prime}$ & 920 \\
\hline 8. E of Wondecla (QLD) & 11 & $17^{\circ} 23^{\prime}$ & $145^{\circ} 28^{\prime}$ & 900 \\
\hline 9. S of Ravenshoe (QLD) & 16 & $17^{\circ} 47^{\prime}$ & $145^{\circ} 32^{\prime}$ & 850 \\
\hline 10. Ravenshoe (QLD) & 8 & $17^{\circ} 42^{\prime}$ & $145^{\circ} 29^{\prime}$ & 950 \\
\hline 11. Mt Spec S.F. (Paluma-QLD) & 35 & $18^{\circ} 57^{\prime}$ & $146^{\circ} 08^{\prime}$ & 950 \\
\hline 12. Clonal Seed Orchard (Concordia-ARG) & 8 & $31^{\circ} 22^{\prime}$ & $58^{\circ} 06^{\prime} \mathrm{W}$ & 30 \\
\hline TEST SITE & & & $(\mathbf{W})$ & \\
\hline 1. Virasoro (Corrientes-ARG) & & $28^{\circ} 13^{\prime}$ & $56^{\circ} 05^{\prime}$ & 114 \\
\hline 2. Cerro Azul (Misiones-ARG) & & $27^{\circ} 39^{\prime}$ & $55^{\circ} 26^{\prime}$ & 274 \\
\hline 3. Cerro Moreno (Misiones-ARG) & & $27^{\circ} 00^{\prime}$ & $54^{\circ} 51^{\prime}$ & 495 \\
\hline
\end{tabular}

Table 1. - Number of families by origin and geographic location of Eucalyptus grandis origins and test sites included in the study.

† QLD: Queensland, Australia; ARG: Argentine. 
where $\ln (V O L), \ln (D B H)$ and $\ln (H T)$ are the natural logarithms of total volume in $\mathrm{m}^{3}, \mathrm{DBH}$ in $\mathrm{cm}$, and total height in $\mathrm{m}$, respectively, at the same measurement age.

Pylodyn pin penetration was measured at $1.30 \mathrm{~m}$ above ground with a Pilodyn 6J after removing bark at two opposite points on the stem (east-west). The average value of both penetrations was recorded in mm (PILO) for each tree. The Pilodyn is a practical and efficient tool to indirectly measure wood density in standing trees, useful for ranking genotypes (HANsEN, 2000). Previous studies have demonstrated a high genetic correlation between Pilodyn penetration and wood density in Eucalyptus species (GREAVES et al., 1996; MACDONALD et al., 1997, LÓPEZ et al., 2005). Bark thickness was measured with a caliper in the two "windows" made for the Pilodyn measurement, and the average of both measurements was recorded in mm. For analysis, bark thickness (BARK) was expressed as percentage of bark respect to total diameter.

\section{Data analysis and estimation of genetic parameters}

Data were analyzed both separately and combined for all test sites. Only trees existing in the second measurement age were included in the analyses; that is, 63.3, 65.9 , and $56.0 \%$ of the trees initially planted at each site. Several factors contributed to tree mortality, including storm and wind effects, illegal cutting, and within-stand competition. Tree mortality introduced additional environmental variation by modifying actual plot spacing, which might reduce the precision in the estimates of genetic parameters; however, tree survival was similar across seed origins, so we assume the results of the analysis are not biased. In the combined analysis, data were standardized to remove scale effects; each value was divided by the standard deviation of its block. This prevents false GEI caused by differences in phenotypic variances among sites (FALCONER and MACKAY, 1996; WhITE, 1996; MARCó and White, 2002). Unlike other traits, FORM and PILO were not standardized since phenotypic variances were similar across sites.

The variance analysis was performed with the TYPE3 method of the MIXED procedure in SAS (SAS, 1996), to determine the significance of differences among seed origins and among families within seed origins. For estimation of variance components, the REML method in the same procedure was used, with the following mixed linear model for the combined analysis:

$$
Y_{i j k l}=\mu+S_{l}+B_{i(l)}+O_{j}+S O_{l j}+F_{k(j)}+S F_{l k(j)}+\varepsilon_{i j k l}
$$

where $Y_{i j k l}$ is the observed trait value in the $i$-th block of the $l$-th site, pertaining to $k$-th family from the $j$-th seed origin; $\mu$ is the overall mean value; $S_{l}$ is the effect of the $l$-th test site; $B_{i}$ is the effect of the $i$-th block; $O_{j}$ is the effect of the $j$-th seed origin; $F_{k(j)}$ is the effect of the $k$-th family within the $j$-th seed origin; $\varepsilon_{i j k l}$ is the random error; and the combinations of letters represent the interactions between the corresponding factors. In the separate analysis for each site, the same model was used without including the effect of site and its interactions with other factors. Initially, block, site and seed origin were considered as fixed-effects factors in order to compare the average values among seed origins. However, for estimation of variance components, only block and site were considered as fixed-effects.

To quantify the contribution of genetic variation among seed origins $\left(\sigma^{2}{ }_{O}\right)$ to total genetic variation (seed origins and families $\left(\sigma_{f}^{2}\right)$ ), the following equation was used (LóPEz et al., 2005):

$$
\phi=\frac{\sigma_{O}^{2}}{\left(\sigma_{o}^{2}+\sigma_{f}^{2}\right)}
$$

Type B genetic correlations were estimated at the level of origins $\left(r_{B O}\right)$ and families $\left(r_{B f}\right)$ from the combined analysis, as a way of determining the relative importance of GEI at both levels (YAMADA, 1962):

$$
\begin{aligned}
& r_{B O}=\frac{\sigma_{O}^{2}}{\left(\sigma_{O}^{2}+\sigma_{S O}^{2}\right)} \\
& r_{B f}=\frac{\sigma_{f}^{2}}{\left(\sigma_{f}^{2}+\sigma_{S f}^{2}\right)}
\end{aligned}
$$

where $\sigma_{S O}^{2}$ y $\sigma_{S f}^{2}$ are the estimated variances corresponding to the site-by-origin and site-by-family interaction, respectively; the other components are the same as defined previously.

With the estimated variances for each trait, narrowsense heritability was calculated at the individual-tree level, both for each site (equation 6) and for the combined analysis (equation 8) with the formula described by MARCó and WHITE (2002). Additive variance was calculated as 3 times the family variance, considering a possible effect of family relationship and the presence of full sibs within the open-pollinated families (SQUILLACE, 1974; MARCó and WHITE, 2002). Standard error of heritability for both analyses was calculated using the method proposed by Dickerson (1969), with equations 7 and 9.

$$
\begin{aligned}
& h_{i}^{2}=\frac{3 \sigma_{f}^{2}}{\left(\sigma_{f}^{2}+\sigma_{e}^{2}\right)} \\
& E E\left(h_{i}^{2}\right)=\sqrt{\frac{3^{2} \operatorname{Var}\left(\sigma_{f}^{2}\right)}{\left(\sigma_{f}^{2}+\sigma_{e}^{2}\right)^{2}}} \quad(7) ; \text { single site } \\
& h^{2}=\frac{3 \sigma_{f}^{2}}{\left(\sigma_{f}^{2}+\sigma_{S f}^{2}+\sigma_{e}^{2}\right)} \\
& E E\left(h^{2}\right)=\sqrt{\frac{3^{2} \operatorname{Var}\left(\sigma_{f}^{2}\right)}{\left(\sigma_{f}^{2}+\sigma_{S f}^{2}+\sigma_{e}^{2}\right)^{2}}} \quad(9) ; \text { combined analysis }
\end{aligned}
$$

where $\operatorname{Var}\left(\sigma_{f}^{2}\right)$ is the variance of the family variance estimate; the other components are the same as defined previously.

Phenotypic and genetic correlations between traits were also calculated, at both the same and different ages. Phenotypic correlations were calculated as Pearson product-moment coefficients of correlation using the CORR procedure of SAS (SAS, 1996). Genetic correlations $\left(r_{g}(x, y)\right)$ were calculated using the typical equation (equation 10) described by FALCONER and MACKAY 
(1996). The genetic covariance between two traits $\left(\operatorname{Cov}_{f(x, y)}\right)$ was calculated with the procedure described by WhiTE and Hodge (1989) using equation 11. The standard error of genetic correlations $\left(\mathrm{EE}\left(r_{g}\right)\right)$ was estimated following the procedure described by FALCONER and MACKAY (1996) with equation 12.

$$
\begin{aligned}
& r_{g(x, y)}=\frac{\operatorname{Cov}_{f(x, y)}}{\sqrt{\left(\sigma_{f(x)}^{2} \sigma_{f(y)}^{2}\right)}} \\
& \operatorname{Cov}_{f(x, y)}=\frac{\sigma_{f(x+y)}^{2}-\left(\sigma_{f(x)}^{2}+\sigma_{f(y)}^{2}\right)}{2} \\
& E E\left(r_{g}\right)=1-r_{g}^{2} \sqrt{\frac{E E\left(h_{x}^{2}\right) E E\left(h_{y}^{2}\right)}{2 h_{x}^{2} h_{y}^{2}}}
\end{aligned}
$$

\section{Results and Discussion}

\section{Differences across sites}

Significant differences among sites were found in tree growth (Table 2). Site 3 was the most productive, with higher average values for $\mathrm{DBH}, \mathrm{HT}$ and VOL at the two ages measured. Average annual growth rate in volume at 8.5 years of age varied from $38 \mathrm{~m}^{3} \mathrm{ha}^{-1}$ in Site 2 , to $50 \mathrm{~m}^{3} \mathrm{ha}^{-1}$ in Site 3 . Site productivity was within the expected range for $E$. grandis in the region (SÁNCHEZAcosta and VerA, 2005). MARCó and White (2002) reported annual growth rates of 35 to $64 \mathrm{~m}^{3} \mathrm{ha}^{-1}$ for the same species at ages 3 to 5 years in nearby sites. Site heterogeneity, measured by the coefficient of phenotypic variation, also increased with productivity. Despite variation in site productivity, average values for BARK and PILO were similar across sites, as were their coefficients of phenotypic variation. Average values of FORM were also similar among sites; however, given that this trait was measured with a site-adjusted scale, this result was expected.
Both the separate and combined analyses showed statistical significance $(p<0.05)$ for all traits among seed origins and among families within origins. The site-byorigin interaction was also significant for all traits, except FORM (at both ages), while the site-by-family interaction was significant only for Pilodyn penetration. Local trees generally exhibited higher growth (Sites 1 and 3) and stem straightness, but also deeper Pilodyn penetration (i.e., lower wood density, Figure 1). This local land race is not currently used in operational plantings, but it has been used as control for all progeny tests established by INTA in the breeding program for $E$. grandis. Compared against seed origins from higher latitude $\left(28^{\circ}\right.$ to $\left.33^{\circ} \mathrm{S}\right)$, the local land race has an average growth performance (MARCó and WHITE, 2002).

\section{Variance components and heritability}

Test in Site 1 had better control of environmental variation in growth traits (DBH, HT and VOL), with a lower error variance component than in other sites. In contrast, FORM, BARK and PILO showed similar proportion of environmental variance at all sites. In the combined analysis, the error variance represented $91 \%$ of total variance for growth traits, $85 \%$ for FORM and BARK and $81 \%$ for PILO. Based on the magnitude of variance components for family and seed origin, traits were separated in two groups: DBH, HT and VOL had much higher variance components at the family level that at the seed origin level, while in FORM, BARK and PILO the difference between the two variance components is less marked (Table 3). Thus, it would be possible to obtain important gains in FORM, BARK and PILO by selecting seed origins, whereas the gains in $\mathrm{DBH}, \mathrm{HT}$ and VOL from selection of seed origins would be quite low. MACDONALD et al. (1997) found similar genetic structures in $E$. globulus, with $\varnothing$ values close to 0.30 for $\mathrm{DBH}$ and 0.50 for Pilodyn. In E. urophylla, the variance fraction due to seed origin for $\mathrm{DBH}$ and height

Table 2. - Average values per site for the traits evaluated ( \pm standard deviation) in the seed origin/progeny test of Eucalyptus grandis evaluated at 4.5 and 8.5 years.

\begin{tabular}{lrcc}
\hline \multicolumn{1}{c}{ Trait } & Site 1 (Virasoro) & Site 2 (Cerro Azul) & Site 3 (Cerro Moreno) \\
\hline DBH_01 (cm) & $17.54 \pm 3.25$ & $15.59 \pm 3.82$ & $19.87 \pm 3.03$ \\
HT_01 (m) & $18.82 \pm 1.76$ & $19.13 \pm 2.86$ & $22.32 \pm 2.04$ \\
VOL_01 (m) & $0.22 \pm 0.09$ & $0.18 \pm 0.10$ & $0.32 \pm 0.11$ \\
FORM_01 & $2.41 \pm 0.92$ & $2.32 \pm 0.96$ & $2.30 \pm 0.87$ \\
DBH_05 (cm) & $22.64 \pm 5.34$ & $20.33 \pm 5.85$ & $24.31 \pm 4.89$ \\
HT_05 (m) & $26.21 \pm 3.68$ & $25.83 \pm 5.14$ & $27.46 \pm 3.29$ \\
VOL_05 (m) & $0.51 \pm 0.26$ & $0.43 \pm 0.29$ & $0.60 \pm 0.27$ \\
FORM_05 & $2.60 \pm 1.07$ & $2.39 \pm 1.02$ & $2.45 \pm 1.06$ \\
BARK (\%) & $7.04 \pm 1.74$ & $7.04 \pm 1.61$ & $7.30 \pm 1.35$ \\
PILO (mm) & $12.22 \pm 2.08$ & $13.91 \pm 2.09$ & $12.94 \pm 1.96$
\end{tabular}

DAP_01, HT_01, VOL_01 and FORM_01 are diameter at $1.3 \mathrm{~m}$, total height, total volume and stem straightness, respectively, evaluated at 4.5 years. DAP_05, HT_05, VOL_05, FORM_05, BARK and PILO are diameter at $1.3 \mathrm{~m}$, total height, total volume, stem straightness, bark thickness and Pilodyn penetration, respectively, evaluated at 8.5 years. 

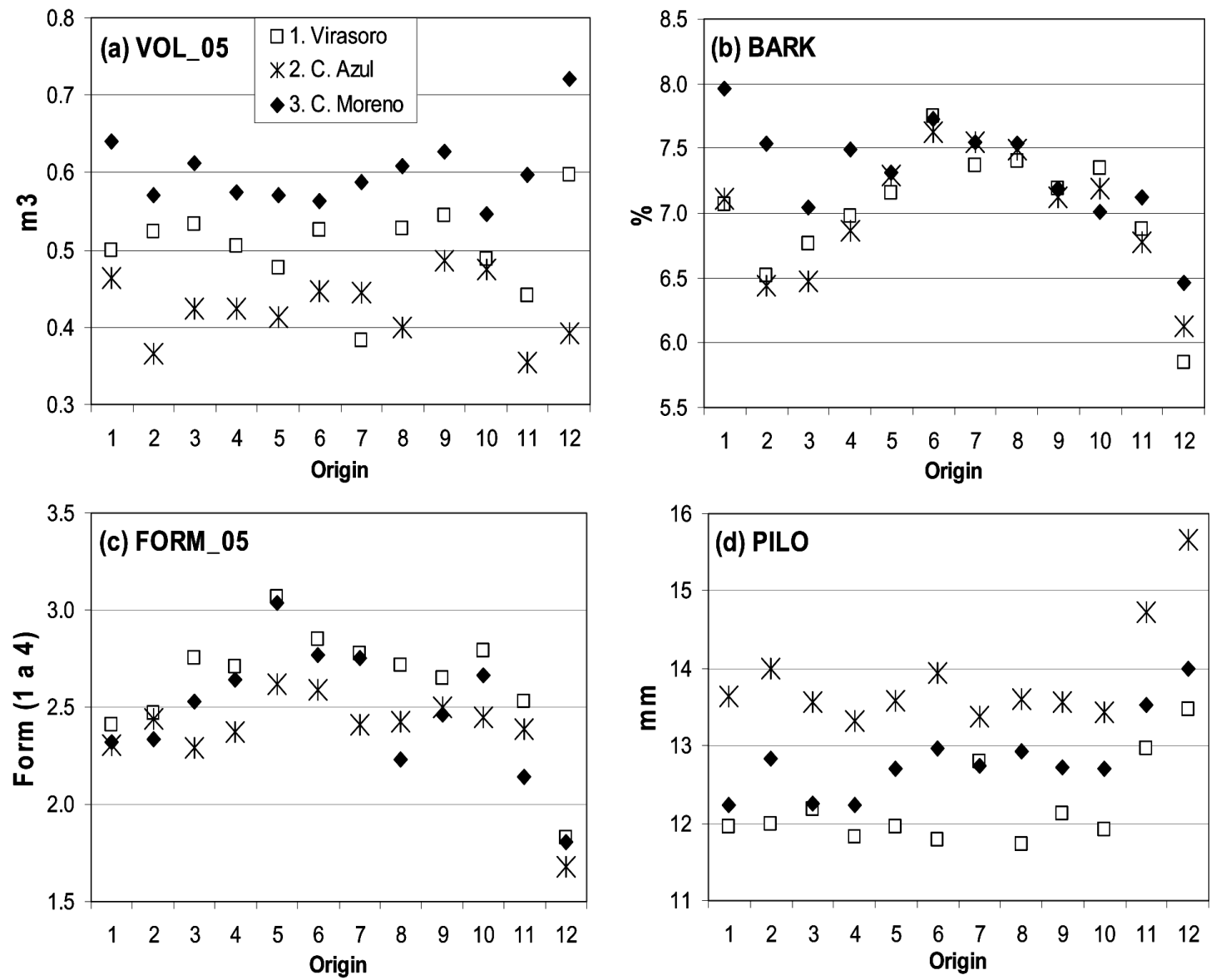

Figure 1. - Average values at the origin level at 8.5 years of age for (a) volume, (b) bark proportion, (c) stem straightness and (d) Pilodyn penetration, in the seed origin/progeny test of Eucalyptus grandis in tree sites of northeastern Argentina.

was very small (WEI and BORRALHO, 1998). LÓPEZ et al. (2005) found $\varnothing$ values of 0.22 to 0.44 for Pilodyn penetration in $E$. grandis, similar to those found in our study. WEI and BORRALHO (1997) also found a major effect of seed origin on bark proportion in $E$. urophylla, but this effect was negligible on Pilodyn penetration.

Using the criteria of COTTERILL and DEAN (1990), most traits showed moderate to high heritability values across sites (Table 4), despite the among-plot variation introduced by tree mortality. For each site, heritability expresses the level of genetic and environmental control. As White and Hodge (1989) indicated, a large experimental error implicates less precise measurements, and therefore low heritability estimates. Estimated heritability in growth traits at Site $1(0.34$ to 0.37$)$ was two to three times higher than in the other sites $(0.07$ to 0.18) at both ages. In contrast, heritability for FORM and BARK was similar across sites. PILO had higher heritability than the other traits; although values for PILO did not differ much among sites, the highest estimate was found in Site 3.

A slight increase over time was observed for heritability of growth and stem form traits across sites (Table 4), but differences among ages were within the standard error of the estimates. Many studies have pointed out that heritability for growth traits commonly increases with age, as in Eucalyptus hybrids (Bouvet and
Vigneron, 1995), E. urophylla (WEI and BorralHo, 1998), Pinus ayacahuite (FARFÁN-VÁZQUEZ et al., 2002) and P. elliottii (LÓPEZ, 2006), among others. A marked increase in heritability between young and adult ages decreases efficiency of response in early selection, so determining the magnitude and direction of this change is important to outline the selection strategy. Given that no major changes in heritability were observed, the efficiency of early selection will primarily depend on genetic correlations between measurements at different ages.

Estimated heritability in the combined analysis was lower than the average of the three sites, but with a lower estimation error (Table 4), showing the confounded effect of the GEI component in the single site analyses. Growth traits were less heritable, followed by FORM and BARK. Pilodyn penetration had heritability values two to three times higher than those for growth traits.

Heritability values for growth traits and FORM were found within the range published by several authors for the same (RoCHA et al., 2006; MARCó and WHITE, 2002) and other Eucalyptus species (BORRALHO et al., 1992; MARQUeS et al., 1996; PAUlA et al., 1996; IPINZA et al., 1997; WeI and BorRALHo, 1998; SÁNCHEZ-VARGAS et al., 2004). Heritability values reported for Pilodyn penetration (WeI and BorRalHo, 1997; KUBE and RAYMOND, 2002; LÓPEZ et al., 2005) are higher than those found 
Table 3. - Proportion of variance components $(\varnothing)$ at the origin level, with respect to the sum of the components origin and family, and type-B genetic correlation at the origin $\left(r_{B O}\right)$ and family $\left(r_{B f}\right)$ levels.

\begin{tabular}{|c|c|c|c|c|c|c|}
\hline \multirow[t]{2}{*}{ Trait } & \multicolumn{4}{|c|}{$\phi$} & \multirow[t]{2}{*}{$r_{B O}$} & \multirow[t]{2}{*}{$r_{B f}$} \\
\hline & Site 1 & Site 2 & Site 3 & Combined & & \\
\hline DBH_01 & 0.26 & 0.30 & 0.43 & 0.14 & 0.31 & 0.71 \\
\hline HT_01 & 0.32 & 0.38 & 0.26 & 0.13 & 0.21 & 0.60 \\
\hline VOL_01 & 0.22 & 0.33 & 0.36 & 0.10 & 0.23 & 0.71 \\
\hline FORM_01 & 0.44 & 0.42 & 0.41 & 0.51 & 0.97 & 0.75 \\
\hline DBH_05 & 0.19 & 0.23 & 0.25 & 0.09 & 0.29 & 0.68 \\
\hline HT_05 & 0.23 & 0.32 & 0.16 & 0.06 & 0.17 & 0.68 \\
\hline VOL_05 & 0.13 & 0.27 & 0.17 & 0.02 & 0.09 & 0.71 \\
\hline FORM_05 & 0.40 & 0.34 & 0.56 & 0.49 & 0.94 & 0.82 \\
\hline BARK & 0.44 & 0.55 & 0.42 & 0.46 & 0.82 & 0.82 \\
\hline PILO & 0.34 & 0.53 & 0.27 & 0.35 & 0.89 & 0.93 \\
\hline
\end{tabular}

Table 4. - Individual-tree heritability $\left(h^{2}\right)$ at each site and in the combined analysis, in the seed origin/progeny test of Eucalyptus grandis evaluated at 4.5 and 8.5 years.

\begin{tabular}{lcccc}
\hline \multicolumn{1}{c}{ Trait } & Site 1 & Site 2 & Site 3 & Combined \\
\hline DBH_01 & $0.34(0.08)^{\dagger}$ & $0.08(0.04)$ & $0.12(0.05)$ & $0.13(0.03)$ \\
HT_01 & $0.37(0.08)$ & $0.09(0.05)$ & $0.09(0.04)$ & $0.11(0.03)$ \\
VOL_01 & $0.35(0.08)$ & $0.07(0.04)$ & $0.14(0.05)$ & $0.14(0.03)$ \\
FORM_01 & $0.27(0.07)$ & $0.24(0.07)$ & $0.29(0.06)$ & $0.20(0.04)$ \\
DBH_05 & $0.37(0.08)$ & $0.11(0.05)$ & $0.16(0.05)$ & $0.15(0.03)$ \\
HT_05 & $0.34(0.08)$ & $0.10(0.05)$ & $0.14(0.05)$ & $0.14(0.03)$ \\
VOL_05 & $0.36(0.08)$ & $0.10(0.04)$ & $0.18(0.05)$ & $0.16(0.03)$ \\
FORM_05 & $0.32(0.07)$ & $0.25(0.07)$ & $0.22(0.06)$ & $0.22(0.04)$ \\
BARK & $0.27(0.07)$ & $0.19(0.06)$ & $0.31(0.07)$ & $0.21(0.04)$ \\
PILO & $0.37(0.08)$ & $0.26(0.07)$ & $0.45(0.08)$ & $0.35(0.06)$ \\
\hline
\end{tabular}

$\dagger$ Standard error of estimate in parenthesis.

here; however, our heritability estimate used only the family within-origin component, without including the variance component among origins which weighed heavily in this trait.

\section{Genetic stability}

At the seed origin level, Type-B genetic correlations $\left(r_{B O}\right)$ showed two distinctive patterns (Table 3). FORM, BARK and PILO had high $r_{B O}$ values $(>0.8)$, exhibiting high genetic stability across sites. In contrast, $r_{B O}$ for $\mathrm{DBH}, \mathrm{HT}$ and VOL was below 0.30. The imbalance in number of families within origins across sites and/or the performance of the local land race might have contributed to this strong GEI of growth traits. As can be seen in Figure 1, trees from the local control grew less than expected at Site 2, based on their relative growth at the other sites. When the local source is excluded from the analysis, and only the families common to all sites are included, $r_{B O}$ for growth traits increases up to 0.6. The local control is from a small clonal seed orchard and, therefore, genetic diversity may be lower than that of seed from natural Australian stands; in addition, this local source included phenotypically selected individuals in the northeastern region of the Entre Ríos Province, where soil conditions differ from those at the evaluation sites.

At the family within-seed origin level, all traits showed moderate to high genetic stability across sites $\left(r_{B f} \geq 0.60\right)$; FORM, BARK and PILO had $r_{B f}$ values slightly higher than DBH, HT and VOL (Table 3). Even though GEI for families was statistically significant $(\mathrm{p}<0.05), r_{B f}$ values did not indicate drastic ranking changes of families across sites, so a single breeding population could be used for the study region. SHELBOURNE (1972) mentions that $r_{B}$ values above 0.67 indicate genetic stability, but lower values affect selection 
efficiency if GEI is ignored. In this study, only HT_01 had a $r_{B f}$ value below 0.67 ; thus, using the previous criterion, GEI at the family level was not important for most traits. Similar results have been found by MARCó and White (2002) and LóPEZ et al. (2005) in E. grandis, MACDONALD et al. (1997) in E. globulus, WEI and BoRRALHO (1998) in E. urophylla, and KUBE and RAYMOND (2002) in $E$. nitens. It is important to mention, however, that the $r_{B O}$ and $r_{B f}$ values show a different genetic structure for $\mathrm{DBH}, \mathrm{HT}$ and VOL as compared to the other traits; growth traits had higher GEI, particularly at the seed origin level.

\section{Phenotypic and genetic correlations among traits}

Correlations between traits varied across sites. However, differences in phenotypic correlations across sites were low and no sign changes were involved, whereas genetic correlations varied widely, with sign changes in some cases (data not presented). These results warn of the bias generally obtained when genetic correlations between traits are based on single-site data, and their potential effect when estimating correlated responses, despite the low genotype-by-environment interaction.

In the combined analysis, a positive phenotypic correlation among DBH, HT and VOL was observed, with values above 0.50 ; VOL had higher correlations with DBH than with HT (Table 5). FORM correlated negatively with growth traits at both ages; although weak, this correlation indicates that trees growing faster had straighter stem. PILO also correlated negatively $\left(-0.35 \leq \mathrm{r}_{\mathrm{p}} \leq-0.27\right)$ with DBH, HT and VOL; hence, Pilodyn tended to penetrate less in trees with higher growth rate. In contrast, FORM and PILO correlated positively, although weakly $\left(r_{p} \leq 0.11\right)$; that is, more twisted trees tended to exhibit greater pin penetration.

Genetic correlations among growth traits were higher than phenotypic correlations $\left(r_{g}>0.80\right)$, with low estimation errors; on the other hand, FORM had very low genetic correlations with all traits, with high standard errors, indicating genetic independence. BARK correlated negatively with $\mathrm{DBH}, \mathrm{HT}$ and VOL, which is desirable for wood production (less bark and therefore less waste in lumber production). PILO was negatively correlated with growth traits and positively with FORM; although in both cases the genetic correlation was relatively weak, the sign is favorable since selection for faster growth and stem straightness would cause a slight increase in wood density as a correlated response. The only unfavorable genetic correlation was between PILO and BARK $\left(r_{g}=-0.44\right)$, indicating that selection for denser wood (less Pilodyn penetration) would cause a slight increase in the proportion of bark.

The structure of genetic correlations found in this $E$. grandis population is similar to what has been found in other Eucalyptus species, except for the correlation between growth and wood density. For example, it is common to find strong positive correlations between growth traits (MATHESON and MULLIN, 1987; IPINZA et al., 1997; WEI and BoRRALHO, 1997), as well as between these and stem straightness (MATHESON and MULLIN, 1987), and negative correlations with relative bark thickness (WEI and BoRRALHO, 1997). On the other hand, several studies show that the genetic correlation between growth rate and wood density in Eucalyptus is negative (BORRALHO et al., 1992; WeI and BORRALHO, 1997; MacDonald et al., 1997; KUBE and RAYMOND, 2002), although in some cases positive values (MouRA et al., 1987; BORRALHO et al., 1992), or values close to zero (IGNACIO-SÁNCHEZ et al., 2005) have also been found. WEI and BORRALHO (1997) also found an unfavorable correlation between wood density and bark proportion in E. urophylla.

For traits measured at ages 4.5 and 8.5 years, age-age genetic correlations were very high $\left(r_{g}>0.90\right)$, suggesting that early selection is feasible, with an important gain in time for the breeding program. MARQUES et al. (1996) estimated similar age-age correlations for $\mathrm{DBH}$ in E. cloeziana at 29 and 80 months of age; WEI and BORRALHO (1998) also found high age-age correlations for $\mathrm{DBH}$ and height, especially after the first year of age. Although age-age correlations include an autocorrelation effect, the values do not generally change much when this effect is excluded (LAMBETH et al., 1983).

Table 5. - Phenotypic (under the diagonal) and genetic (above the diagonal) correlations between traits from the combined analysis across sites.

\begin{tabular}{lccllllllll}
\hline & DBH_01 & HT_01 & VOL_01 & FORM_01 & DBH_05 & HT_05 & VOL_05 & FORM_05 & BARK & PILO \\
\hline DBH_01 & & $0.82(0.06)^{\dagger}$ & $1.02(-0.01)^{\natural}$ & $0.01(0.15)$ & $0.98(0.01)$ & $0.89(0.04)$ & $0.98(0.01)$ & $-0.08(0.15)$ & $-0.27(0.14)$ & $-0.17(0.14)$ \\
HT_01 & 0.76 & & $0.86(0.05)$ & $-0.12(0.16)$ & $0.82(0.06)$ & $0.91(0.03)$ & $0.84(0.05)$ & $-0.21(0.15)$ & $-0.38(0.14)$ & $-0.34(0.13)$ \\
VOL_01 & 0.91 & 0.63 & & $-0.02(0.15)$ & $1.00(0.00)$ & $0.94(0.02)$ & $0.99(0.00)$ & $-0.13(0.15)$ & $-0.28(0.14)$ & $-0.20(0.13)$ \\
FORM_01 & -0.19 & -0.08 & -0.26 & & $-0.03(0.15)$ & $-0.14(0.15)$ & $-0.07(0.15)$ & $1.05(-0.01)$ & $0.07(0.14)$ & $0.21(0.12)$ \\
DBH_05 & 0.93 & 0.64 & 0.94 & -0.26 & & $0.91(0.03)$ & $1.00(0.00)$ & $-0.15(0.14)$ & $-0.32(0.13)$ & $-0.18(0.13)$ \\
HT_05 & 0.88 & 0.85 & 0.74 & -0.17 & 0.80 & & $0.95(0.01)$ & $-0.23(0.14)$ & $-0.35(0.13)$ & $-0.28(0.13)$ \\
VOL_05 & 0.80 & 0.50 & 0.94 & -0.30 & 0.93 & 0.66 & & $-0.19(0.14)$ & $-0.32(0.13)$ & $-0.18(0.13)$ \\
FORM_05 & -0.21 & -0.08 & -0.31 & 0.70 & -0.31 & -0.17 & -0.37 & & $0.13(0.13)$ & $0.16(0.12)$ \\
BARK & 0.20 & 0.08 & 0.08 & 0.06 & 0.12 & 0.18 & 0.01 & 0.05 & -0.12 & $-0.44(0.10)$ \\
PILO & -0.30 & -0.27 & -0.32 & 0.09 & -0.35 & -0.31 & -0.35 & 0.11 & -0.16 & \\
\hline
\end{tabular}

$\dagger$ Standard error of estimate in parenthesis.

$\mathbb{I}$ Correlation estimates above 1.00 or negative standard errors, are faults from the estimation method.

$\S$ With the exception of BARK/VOL_05, all the phenotypic correlations are significant with $p=0.05$. 


\section{Conclusions}

Results of the study demonstrate that Eucalyptus grandis is a species with enormous productive potential for commercial plantations in Northeastern Argentina, where the local land race grew better than the seed origins from Northeastern Queensland included in the test, but with less dense wood; thus, it might be possible to infuse new genetic variation into the current breeding population in the region. A wide genetic variation was found for all traits evaluated, but the genetic structure and degree of genetic control differed among them. Selection within origins should be emphasized for growth traits, whereas for stem straightness, bark proportion and Pilodyn penetration, selection among seed origins would also be important to incorporate this genetic variation into the breeding program. Genetic correlations among sites are high enough for all traits, particularly at the family level, suggesting that GEI would not affect the selection program. Therefore, it is feasible to work with a single breeding population for the study region.

Except for the correlation between Pilodyn penetration and bark proportion, all genetic correlations between traits evaluated were favorable in magnitude and sign, so it is possible to conduct a breeding program handling these traits, either independently or combined, without negative correlated effects. For example, it is feasible to select for increased lumber production with lower proportion of bark and higher wood density without affecting stem straightness. Age-age correlations for growth traits and stem straightness were quite high $(>0.90)$, so there is potential for early selection in these traits, with important gains in time for the breeding program.

\section{Acknowledgements}

The authors express their gratitude to M. A. MARCó and J. A. LÓPEZ (h) for their continuous support throughout this research project and their comments on the analysis of data. To J. Pujato, R. Schenone, J. Trabichet, R. Eyman, D. Moledo, E. Almada and M. Carmarán, for their help and support during the establishment and measurement of the field trials. Also, to the Forestal Argentina S. A. company, the EEA INTA Cerro Azul and the Hut family, for providing the land for the field trials and for their logistics support and maintenance of these trials. This research was supported partly by the "Proyecto de Desarrollo Forestal" of the Secretaría de Agricultura, Ganadería, Pesca y Alimentos (SAGPyA) of Argentina and the GEMA Project (II-0266-FA), ALFA Network.

\section{References}

Boland, D. J., M. I. H. Brooker, G. M. Chippendale, N. Hall, B. M. P. Hyland, R. D. Johnston, D. A. KLEINIG and J. D. TuRner (1984): Forest Trees of Australia, $4^{\circ}$ ed. CSIRO. Australia.

Borralho, N. M. G. (1998): Genetics parameters estimation, pp. 301-310. In: Curso Mejora Genética Forestal Operativa, edited by R. IPINZA, B. GutiÉRREz y V. EmHart, Valdivia, Chile. November 16-21.
Borralho, N. M. G., P. P. Cotterill and P. J. Kanowski (1992): Genetic parameters and gains from selection for dry weight in Eucalyptus globulus ssp. globulus in Portugal. For. Sci. 38: 80-94.

Bouvet, J. M. and P. Vigneron (1995): Age trend in variances and heritabilities in Eucalyptus factorial mating designs. Silvae Genet. 44: 206-216.

Braier, G. (2004): Tendencias y Perspectivas del Sector Forestal al año 2020 - Argentina. FAO.

Cotterill, P. P. and C. A. Dean (1990): Successful Tree Breeding with Index Selection. CSIRO Publishing. Division of Forestry and Forest Products. Australia.

Crechi, E., H. Fassola, S. Barth, A. Keller y J. Costa (2006): Comparación para la mesopotamia y ajuste para Misiones - NE de Corrientes, Argentina, de ecuaciones de volumen total para Eucalyptus grandis Hill ex Maiden. In: $12^{\circ}$ Jornadas Técnicas Forestales y Ambientales, UNaM-INTA, Eldorado, Misiones, Argentina. June $8-10$.

Dickerson, G. E. (1969): Techniques for research in quantitative animal genetics, pp. 36-79. In: Techniques and Procedures in Animal Science Research. Amer. Soc. Animal Res. Albany, N.Y.

FALCONER, D. S. and T. F. C. MACKAY (1996): Introduction to Quantitative Genetics. $4^{\circ}$ ed. Addison Wesley Longman Limited. England.

FARFÁn-VÁZqUEZ, E. G., J. JASSO-MATA, J. LóPEZ-Upton, J. J. VARGAS-HERnándeZ y C. RAMírez-HERRERA (2002): Parámetros genéticos y eficiencia de la selección temprana en Pinus ayacahuite Ehren. var. ayacahuite. Rev. Fitotecnia Mexicana 25: 239-246.

Greaves, B. L., N. M. G. Borralho, C. A. Raymond and A. FARRINGTon (1996): Use of a Pilodyn for the indirect selection of basic density in Eucalyptus nitens. Can. J. For. Res. 26: 1643-1650.

Hansen, C. P. (2000): Application of the Pilodyn in forest tree improvement. DFSC Series of Technical Notes. TN55. Danida. Forest Seed Centre, Humlebaek, Denmark.

IgNACIO-SÁnchez, E., J. J. VARgAS-HERnÁNDEZ, J. LóPEZUpton y A. BoRja-De LA Rosa (2005): Parámetros genéticos del crecimiento y densidad de la madera en edades juveniles de Eucalyptus urophylla S.T. Blake. Agrociencia 39: 469-479.

IpINZA, R., B. GuTiÉRRez y M. Molina (1997): Análisis genético univariado de siete ensayos de progenie y procedencia de Eucalyptus nitens (Deane \& Maiden) Maiden en Chile. Potencial genético y silvícola. In: IUFRO Conference Modelling Growth of Fast-Grown Tree Specie. Valdivia, Chile. September 3-5.

Kube, P. and C. RAYmond (2002): Selection strategies for genetic improvement of basic density in Eucalyptus nitens. CRC. Technical Report 92. Tasmania.

Lambeth, C. C., J. P. van BuiJtenen, S. D. Duke and R. B. McCullough (1983): Early selection is effective in 20-year-old genetic test of Loblolly pine. Silvae Genet. 32: $210-215$.

LóPEz, J. A. (2006): Control genético del volumen y eficiencia de la selección temprana en Pinus elliottii Engelm. var. elliottii. In: $12^{\circ}$ Jornadas Técnicas Forestales y Ambientales, UNaM-INTA, Eldorado, Misiones. Argentina. June 8-10.

López, J. A., M. A. Marcó, L. Harrand y P. Y. Genes (2005): Interacción genotipo-ambiente y parámetros genéticos de la densidad de la madera de Eucalyptus grandis utilizando Pilodyn. In: $3^{\circ}$ Congreso Forestal Argentino y Latinoamericano. Corrientes, Argentina. September 6-9. 
MacDonald, A. C., N. M. G. Borralho and B. M. Potts (1997): Genetic variation for growth and wood density in Eucalytus globulus ssp. globulus in Tasmania (Australia). Silvae Genet. 46: 236-241.

Marcó, M. A. and T. L. White (2002): Genetics parameters estimates and genetic gains for Eucalyptus grandis and E. dunnii in Argentina. For. Genet. 9: 205-215.

Marques, O. G., H. B. Andrade and M. A. P. Ramalho (1996): Assessment of the early selection in Eucalyptus cloeziana F. Muell. in the northwest of Minas Gerais state (Brazil). Silvae Genet. 45: 359-361.

Matheson, A. C. and L. J. Mullin (1987): Variation among neighboring and distant provenances of Eucalyptus grandis and E. tereticornis in Zimbabwean field trials. Aust. For. Res. 17: 233-250.

MourA, V. P. G., R. D. BARNES and J. S. BiRKS (1987): A comparison of three methods of assessing wood density in provenances of Eucalyptus camaldulensis Dehnh. and other Eucalyptus species in Brazil. Aust. For. Res. 17: 83-90.

Paula, R. C., R. C. G. Borges, I. E. Pires, N. F. Barros e C. D. CRUZ (1996): Estimativas de parâmetros genéticos em famílias de meios-irmãos de Eucalyptus camaldulensis Dehnh. I. Características de crescimento e densidade da madeira. Rev. Árvore 20: 309-317.

Rocha, M. G. B., I. E. Pires, R. B. Rocha, A. Xavier e C. D. CRuz (2006): Avaliação genética de progênies de meio-irmãos de Eucalyptus grandis por meio dos procedimentos REML/BLUP e da ANOVA. Sci. For. 71: 99-107.

SAGPyA-INTA (2005): Mejores Árboles para más Forestadores: el Programa de Producción de Material de Propagación Mejorado y el Mejoramiento Genético en el Proyecto Forestal de Desarrollo. R. FERnández (Coord.) Secretaría de Agricultura, Ganadería, Pesca y Alimentos. Buenos Aires, Argentina.

SÁNCHEZ-AcostA, M. (1999): Experiencia argentina en la producción y utilización de la madera de eucalipto, panorama a 1999. In: Workshop Técnicas de Abate, Processamento e Utilização da Madeira de Eucalipto, Viçosa, Minas Gerais. Junho 22-24.

SÁNCHEZ-Acosta, M. y L. VeRA (2005): Situación forestoindustrial de Argentina al 2005. In: III Simposio Iberoamericano de Gestión y Economía Forestal. Ubatuba, San Pablo, Brasil. September 18-21.
Sánchez-Vargas, N. M., J. J. Vargas-Hernández, L. M. RUIZ-PosadAS y J. LóPEz-UPTON (2004): Repetibilidad de parámetros genéticos en un ensayo clonal de Eucalyptus urophylla S.T. Blake en el sureste de México. Agrociencia 38: 465-475.

SAS InSTITUTE (1996): SAS/STAT Computer Software. Release 6.12. SAS Institute Inc. Cary, North Carolina, U.S.A.

Shelbourne, C. J. A. (1972): Genotype-environment interaction: Its study and its implications in forest tree improvement, pp. 1-28. In: IUFRO Genetics-SABRAO Joint Symposia. Tokyo.

Squillace, A. E. (1974): Average genetic correlations among offspring from open-pollinated forest-trees. Silvae Genet. 23: 149-156.

van BuiJTEnen, J. P. (1992): Fundamental genetic principles, pp. 29-68. In: Handbook of Quantitative Forest Genetics. Edited by L. Fins, S. T. FRIEDMAN and J. V. Brotschol. Kluwer Academic Publishers, The Netherlands.

VIANA, J. M. S. (2001): Genetic correlations in family structured populations. Rev. Árvore 25: 97-103.

Volker, P. W. and C. A. RAYMond (1988): Potential for breeding eucalypts in Tasmania. Appita J. 41: 25-30.

WeI, X. and N. M. G. BorRalHo (1997): Genetic control of wood basic density and bark thickness and their relationships with growth traits of Eucalyptus urophylla in South East China. Silvae Genet. 46: 245-250.

WEI, X. and N. M. G. BorRalHo (1998): Genetic control of growth traits of Eucalyptus urophylla S.T. Blake in south east China. Silvae Genet. 47: 158-165.

White, T. L. (1996): Genetic parameter estimates and breeding value predictions: issues and implications in tree improvement programs, pp. 110-117. In: Tree Improvement for Sustainable Tropical Forestry, edited by M. J. Dieters, A. C. Matheson, D. G. Nikles, C. E. HARWOOD and S. M. WALKer. Proc. QFRI-IUFRO Conf. Caloundra, QLD, Australia. 27 October-1 November.

White, T. L. and G. R. Hodge (1989): Predicting Breeding Values with Applications in Forest Tree Improvement. Kluwer Academic Publishers, The Netherlands.

YAMADA, Y. (1962): Genotype by environment interaction and genetic correlation of the same trait under different environments. Japan J. Gen. 37: 498-509.

ZoBeL, B. J. and J. T. TALBERT (1984): Applied Forest Tree Improvement. John Wiley \& Sons, New York, U.S.A. 